\title{
Mengenalkan Berdagang Secara Online Melalui Media Sosial kepada Warga di Lokasi Kuliah Kerja Nyata (KKN) Pada Masa Pandemi Covid-19
}

\author{
Venty Suryanti*1, Annisa Puspaning Tiyas ${ }^{2}$, Luthfia Devi Romadhoni ${ }^{3}$ dan Maria Kristi Abilawati \\ Putri Rijatno ${ }^{4}$
}

\author{
${ }^{1}$ Program Studi Kimia, Fakultas Matematika dan Ilmu Pengetahuan Alam, Universitas Sebelas \\ Maret, Jl. Ir. Sutami 36A Surakarta. \\ ${ }^{2}$ Program Studi Pendidikan Guru Sekolah Dasar, Fakultas Keguruan dan Ilmu Pendidikan, \\ Universitas Sebelas Maret, Jl. Ir. Sutami 36A Surakarta. \\ ${ }^{3}$ Program Studi Pendidikan Pancasila dan Kewarganegaraan, Fakultas Keguruan dan Ilmu \\ Pendidikan, Universitas Sebelas Maret, Jl. Ir. Sutami 36A Surakarta. \\ ${ }^{4}$ Program Studi Pendidikan Akutansi, Fakultas Keguruan dan Ilmu Pendidikan, Universitas \\ Sebelas Maret, Jl. Ir. Sutami 36A Surakarta. \\ *venty@mipa.uns.ac.id
}

\begin{abstract}
Abstrak
Pada bulan Mei-Juni 2020 telah dilaksanakan Program Kuliah Kerja Nyata (KKN) oleh mahasiswa Universitas Sebelas Maret (UNS). Dalam masa pandemi Covid-19, KKN dilaksanakan di lokasi tempat tinggal mahasiswa dengan tetap menerapkan protokol kesehatan. Dalam melaksanakan program KKN, pengumpulan masa dihindari. Salah satu program KKN yang sudah dilaksanakan adalah sosialisasi dan implementasi E-commerce kepada warga masyarakat lokasi KKN. Berdagang secara online dengan media sosial wa dan akun Instagram telah dilakukan. Beberapa warga sudah menawarkan barang dagangannya lewat media sosial dan transaksi jual beli juga sudah dilaksanakan. Pendampingan kepada warga masih perlu terus dilakukan untuk mempromosikan barang dagangannya dengan tampilan yang lebih menarik, cara membungkus (packing), mengirim barang dagangan dan pembayaran dengan transfer uang.
\end{abstract}

Kata kunci: Covid-19, E-commerce, Whats App, Instagram, media sosial

\section{Pendahuluan}

Kuliah Kerja Nyata (KKN) adalah kegiatan yang terintegrasi antara pendidikan, penelitian dan pengabdian kepada masyarakat yang dilaksanakan oleh Perguruan Tinggi. Dalam pelaksanaanya, KKN dilakukan oleh mahasiswa dengan bimbingan dosen dan ditambah unsur masyarakat/pemerintah. KKN merupakan wahana untuk menerapkan dan mengembangkan ilmu pengetahuan, teknologi dan seni yang diperoleh Perguruan Tinggi untuk mensukseskan pengembangan manusia dan pembangunan. KKN diharapkan dapat ikut menyelesaikan masalahmasalah yang nyata dihadapi oleh masyarakat (Hadi dkk, 2020). KKN juga bertujuan untuk menumbuhkan rasa percaya diri dan mengembangkan kepekaan rasa dan ketrampilan sosial mahasiswa, karena kegiatan ini mengharuskan mahasiswa berinteraksi secara langsung dengan masyarakat. Keberhasilan pelaksanaan KKN sangat tergantung dari kerjasama yang baik dan keterlibatan yang aktif antara mahasiswa dan masyarakat baik sejak proses pengumpulan data, analisis situasi, perumusan program dan rencana kerja, serta pelaksanaan dan evaluasi hasilnya. Dosen Pembimbing Lapangan (DPL) menggunakan dual mode dalam dalam melaksanakan pendampingan, pembimbingan, monitoring dan evaluasi serta pengembangan kompetensi akademik dan kompetensi sosial mahasiswa, yaitu dengan metode dalam jaringan (daring) dan luar jaringan (luring) melalui 
tatap muka langsung. Dalam masa pandemi Corona Virus Disease-19 (Covid-19), semua yang terlibat dalam pelaksanaan KKN UNS periode Mei-Juni 2020 harus mematuhi social dan physical distancing.

Terus meningkatnya kasus penderita positif Covid-19 di Indonesia menyebabkan sejumlah konsekuensi sosial dan ekonomi. Beberapa tindakan telah diambil guna mencegah penyebaran virus corona tersebut (Harapan, 2020 dan Yuliana, 2020). Dalam konferensi pers di Istana Bogor pada tanggal 16 Maret 2020, Presiden Joko Widodo menyampaikan kebijakan belajar dari rumah, bekerja dari rumah, dan ibadah di rumah untuk mengurangi penyebaran Covid-19. Permerintah juga mengambil kebijakan sekolah dari rumah (school from home) untuk para siswa/mahasiswa. Kampanye agar masyarakat berdiam diri (stay at home) dan jaga jarak (physical distancing) untuk mengurangi risiko terinfeksi virus corona juga terus digalakkan. Kondisi beraktivitas di rumah memiliki sejumlah konsekuensi yang berbeda dengan kondisi normal. Perubahan gaya hidup akibat pandemi Covid-19 tidak bisa dihindari. Pandemi Covid-19 telah menimbulkan dampak negatif utamanya terhadap sektor perekonomian.

Terpuruknya perekonomian di masa pandemi Covid-19 telah dirasakan oleh masyarakat, khususnya mereka yang berada di golongan menengah ke bawah. Masyarakat yang memiliki pendapatan harian sangat terdampak karena mereka tidak ada pendapatan kalau tidak bekerja harian. Pegawai/pekerja informal, pekerja serabutan dan pedagang kecil sangat rentan dengan kemiskinan. Pekerjaan terkait sektor pariwisata juga banyak yang tutup. Penganggungan yang meningkat tidak dapat dihindari. Perlu adanya langkah-langkah untuk mengatasi dampak negatif Covid-19 pada sektor perekonomian. Ekonomi kreatif tingkat rumah tangga harus dikembangkan. Produk barang dan jasa skala rumah tangga yang dapat meningkatkan pendapatan keluarga harus digalakkan untuk memperkokoh ekonomi keluarga (Tohardi, 2002).

Untuk mendukung kebijakan pemerintah terkait pandemi Covid-19 yaitu stay at home, maka UNS melaksanakan kegiatan pendidikan dan pengabdian kepada masyarakat dari rumah. Kegiatan pengajaran dan pendidikan dilakukan secara daring sedangkan kegiatan KKN dilaksanakan oleh mahasiswa secara individu di lokasi sekitar daerah asal/tempat tinggalnya masing-masing. Kegiatan KKN pada masa pendemi Covid-19 ini dilakukan oleh mahasiswa dengan menggunakan media sosial atau media yang lain sesuai dengan protokoler penanganan pandemi Covid-19. Pelaksanaan KKN Mahasiswa UNS selama masa pandemi Covid-19 bertujuan untuk membantu masyarakat dalam proses pencegahan dan penanganan dampak Covid-19 yang sesuai dengan protokol kesehatan yang telah ditetapkan oleh Pemerintah. Dukungan terhadap masyarakat baik terkait sosial, ekonomi dan kesehatan menjadi prioritas program kerja KKN. Salah satu program kerja KKN selama pandemi Covid19 adalah membantu ekonomi masyarakat dengan membuka peluang usaha skala rumah tangga dan membantu pemasaran produksi lokal. E-commerce telah terbukti sangat bermanfaat dalam menjual berbagai produk yang dihasilkan oleh masyarakat dan membantu masyarakat tetap bertahan masa pandemi Covid-19 (Anwar, 2020). Sosialisasi dan implementasi E-commerce pada masyarakat di lokasi KKN menjadi salah satu program KKN UNS di masa pandemi Covid-19.

\section{Metode Pelaksanaan}

KKN dilaksanakan pada bulan Mei-Juni 2020 oleh mahasiswa dengan bimbingan dari Dosen Pembimbing Lapangan (DPL). KKN dilaksanakan oleh mahasiswa secara individu di lokasi sekitar tempat tinggal masingmasing. Kegiatan KKN ini dilaksanakan dengan persetujuan ketua RT masing-masing lokasi KKN. Program kerja direncanakan dan dilaksanakan dengan melibatkan ketua RT dan warga masyarakat di lokasi masing-masing. Tiga lokasi KKN berada di tiga kecamatan di Kabupaten Karanganyar, yaitu:

1. RT 05 RW II Kodokan, Desa Papahan, Tasikmadu, Karanganyar.

2. RT 02 RW V Dukuh Karangan, Ngunut, Jumantono, Karanganyar.

3. RT 03 RW XII Desa Dagen, Jaten, Kabupaten Karanganyar

Mahasiswa melaksanakan kegiatan KKN sesuai dengan protokoler penanganan pandemi Covid-19 dengan menghindari pengumpulan masa. Mahasiswa menggunakan media secara online dengan media sosial. Sebagai alternatif, mahasiswa melaksanakan kegiatan bersama dengan teman yang berada pada wilayah yang berdekatan, dengan tetap melakukan komunikasi secara daring. Pendekatan kelompok terbatas bisa dilakukan dengan teman yang berbeda bidang keahlian sesuai dengan kebutuhan, dengan tetap melakukan komunikasi secara daring.

Urutan pelaksanaan kegiatan untuk mengenalkan dan mempraktekkan E-commerce kepada masyarakat dapat dilihat pada Gambar 1. Sebagai langkah awal dilakukan sosialisasi keunggulan dan cara melaksanakan Ecommerce kepada warga masyarakat. Kegiatan ini kemudian dilanjutkan dengan pendataan nama warga masyarakat yang mempunyai produk atau barang dagangan dan selanjutnya melakukan pendataan produk atau barang dagangan yang akan ditawarkan secara online. Setelah informasi yang akan ditampilkan di WhatsApp (wa) 
group dan Instagram terkumpul, maka selanjutkan adalah pembuatan akun wa group dan Instagram. Tahapan selanjutnya adalah kegiatan promosi dan jual beli melalui wa group dan Instagram. Evaluasi kegiatan kemudian dilaksanakan untuk keberlanjutan pelaksanaan E-commerce oleh masyarakat.

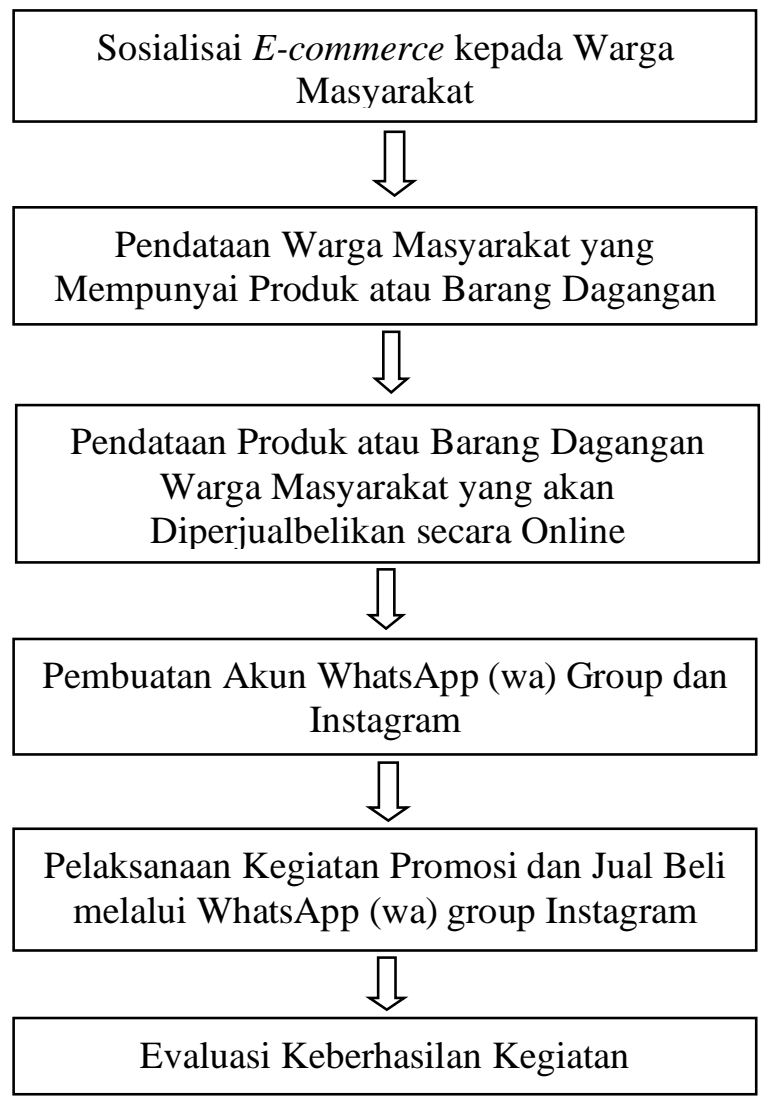

Gambar 1. Alur Pelaksanaan Kegiatan.

\section{Hasil Dan Pembahasan}

Masa pandemi Covid-19 membawa dampak di berbagai bidang. Bidang ekonomi merupakan salah satunya. Anjuran pemerintah untuk stay at home membuat para pengusaha memutar otak dalam menjalankan usahanya. Demi menghindari kepailitan, Pemutusan Hubungan Kerja (PHK) menjadi suatu pilihan. Secara finansial, banyak masyarakat yang mengalami kesulitan dalam pemenuhan kebutuhan. Sedangkan, kebutuhan semakin hari semakin bertambah silih berganti. Maka perlu adanya solusi dalam menghadapi kondisi tersebut. Tidak jarang warga masyarakat yang beralih profesi, yang tadinya bekerja sebagai buruh hingga karyawan kantoran kini beralih menjadi pedagang. Saat ini berdagang menjadi satu pilihan profesi yang dianggap menjanjikan, sebab tidak bergantung pada atasan yang menyuruh lakukan.

Perkembangan teknologi informasi, tertutama internet merupakan faktor pendorong berkembangnya perdagangan melalui elektronik atau biasa disebut dengan E-commerce. Kegiatan transaksi dagang yang dilakukan oleh pihak penyedia produk/barang (penjual) dengan pihak yang membutuhkan produk (pembeli) yang meliputi pembelian, penjualan, pemasaran barang atau jasa dapat dilakukan melalui sistem elektronik dengan media internet, web, komputer, handphone, dan jaringan lainnya. E-commerce dapat memudahkan dalam menjalankan perdagangan baik sisi komunikasi untuk mendapatkan informasi, mempromosikan, memasarkan barang atau jasa dan pembayaran. Dengan perdagangan secara elektronik dapat memudahkan penjual dan pembeli untuk berkomunikasi tanpa harus bertemu langsung (Tanoto, 2019; Ardiana dan Subaedi, 2010).

E-commerce berkembang sangat pesat. Kemudahan mengakses internet yang murah dan cepat menyebabkan meningkatkan jumlah pengguna internet. Persaingan dagang yang sangat ketat membuat penjual harus meningkatkan potensi pemasarannya, salah satunya dengan menggunakan internet. Penjual dapat memasarkan dagangannya ke tempat yang lebih luas bahkan bisa ke seluruh dunia. Masyarakat dalam melakukan transaksi jual 
beli ingin lebih fleksibel dengan tidak perlu ketemu secara langsung. Masyarakat secara perlahan melakukan belanja dan pembayaran secara online dan mulai meninggalkan berbelanja di toko. Pedagang dan konsumen akan menghemat tenaga, waktu, tempat dan biaya (Siregar dan Widodo, 2018; Gambrien, 2012; Sari, 2018). Pandemi Covid-19 mempengaruhi banyak bidang termasuk juga ekonomi. Proses penjualan produk-produk yang dihasilkan oleh masyarakat yang biasanya dijual secara manual di pasar atau di toko menjadi susah terjual karena efek pandemi di mana warga dilarang ke luar rumah. Proses penjualan selanjutnya dilakukan secara online melalui media sosial agar hasil usahanya tetap terjual.

Program kerja yang dilaksanakan di lokasi KKN adalah membantu masyarakat di lokasi KKN untuk memasarkan dagangannya melalui media sosial, seperti wa group dan Instagram. Program ini bertujuan untuk mempromosikan barang dan jasa yang dijual atau ditawarkan oleh warga di lokasi KKN sehingga dapat membantu ekonomi masyarakat. Karena sebagaian besar warga masyarakat lokasi KKN belum mengetahui seluk-beluk E-commerce, maka pertama kali adalah dilakukan sosialisasi E-commerce kepada masyarakat. Keuntungan dan tatacara pelaksanaan berdagang secara online dengan media sosial dikenalkan kepada warga masyarakat. Materi tips dan trik berdagang secara online telah disampaikan di lokasi KKN dan telah mendapat respon positif dari warga setempat. Masyarakat menjadi paham dan mau menerapkan pengetahuan yang diperoleh.

Setelah masyarakat memahami seluk-beluk E-commerce, kemudian dilakukan pendataan bagi masyarakat yang bersedia untuk mengikuti jual beli secara online. Ada beberapa masyarakat yang langsung bersedia mendaftarkan dirinya, tetapi ada beberapa warga yang masih ragu untuk melaksanakan berdagang secara online. Masyarakat yang masih ragu ini selanjutnya diberi pengertian lagi tentang keuntungan jual beli secara online. Kegiatan selanjutnya adalah mengumpulkan data dan gambar/foto tentang produk yang dihasilkan warga masyarakat baik produk hasil pertanian maupun hasil industri rumah tangga serta barang dagangan lain dari warga.

Tahapan berikutnya adalah penerapan E-commerce bagi masyarakat, yang didahului dengan pembuatan akun wa group dan Instagram. Tahapan selanjutnya adalah menampilkan barang dagangan warga masyarakat dalam wa group atau di akun Instagram. Warga masyarakat juga diperbolehkan untuk mempromosikan barang dagangan sendiri. Hal tersebut nampak pada beberapa warga yang sudah mau dan mampu memberanikan diri untuk promosi dagangan pada status wa grup dan akun Instagram. Warga RT 05 RW 02 Kodokan, Desa Papahan, Kecamatan Tasikmadu, Kabupaten Karanganyar membuat wa group dengan nama "Dasawisma Rt 05 Kodokan" untuk memasarkan dagangannya. Barang dagangan yang sudah dipasarkan melalui wa group tersebut meliputi bahan pangan, sandang dan produk kesehatan (Gambar 2).
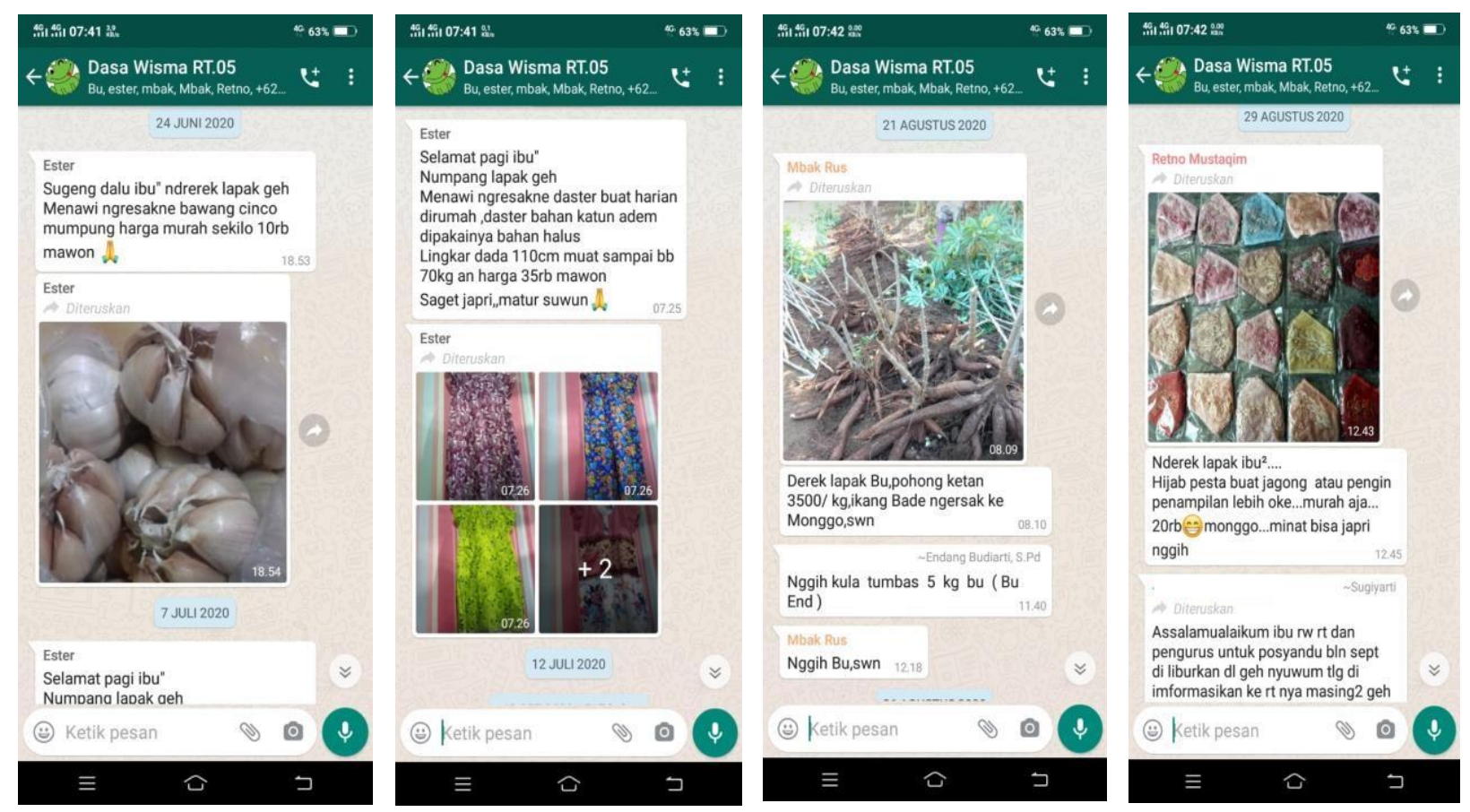

Gambar 2. Whats App (wa) group "Dasawisma Rt 05 Kodokan” yang dibuat untuk media berdagang warga RT 05 RW 02 Kodokan, Desa Papahan, Kecamatan Tasikmadu, Kabupaten Karanganyar. 
Barang dagangan warga RT 02 RW V, Dukuh Karangan, Ngunut, Jumantono, Karanganyar dipromosikan dalam akun Instagram dengan nama "umkm.dkkaranganrt02" (Gambar 3). Barang dagangan warga RT 03 RW XII Desa Dagen, Kecamatan Jaten, Kabupaten Karanganyar ditawarkan dalam akun Instagram "grebegumkmdagenpalur" (Gambar 4).
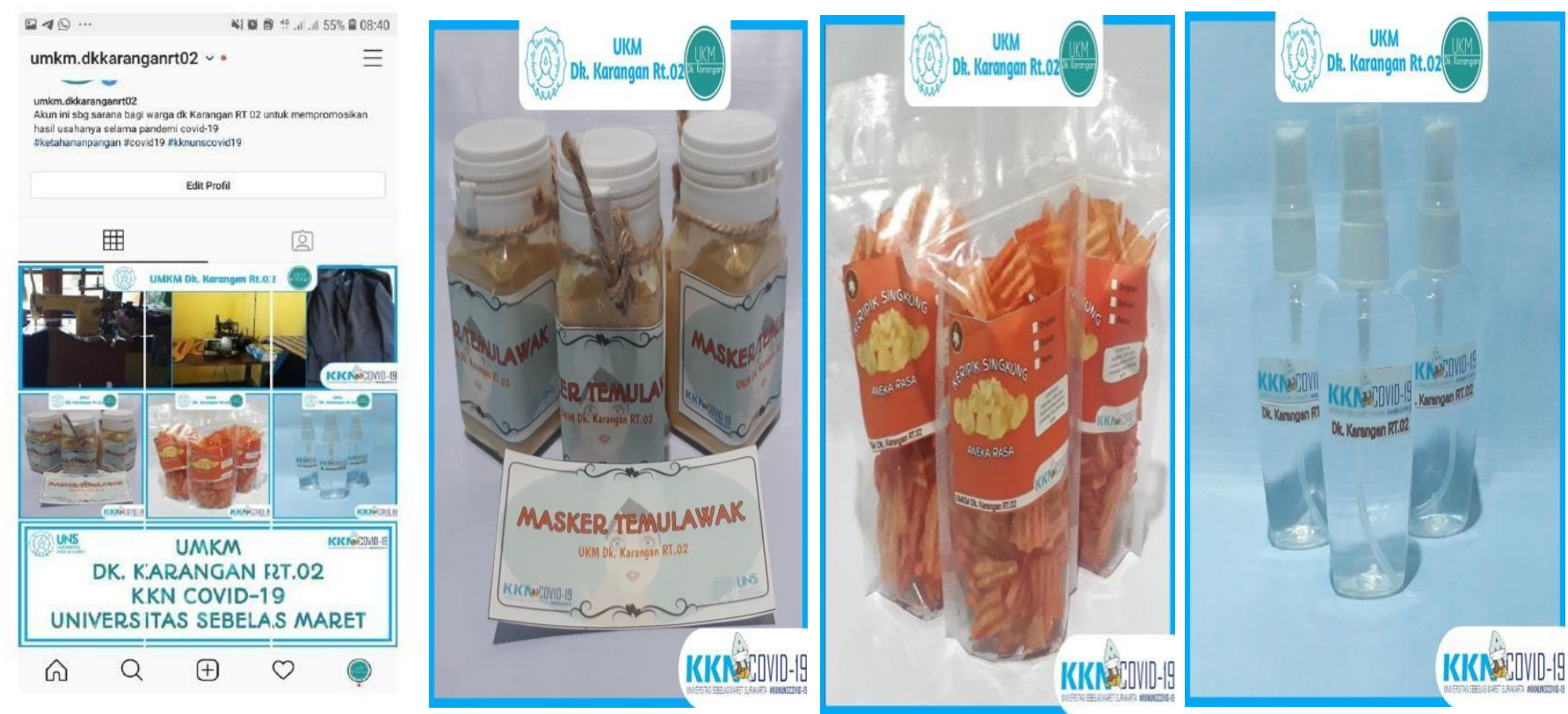

Gambar 3. Akun Instagram “umkm.dkkaranganrt02” dan beberapa contoh dagangan yang ditawarkan.
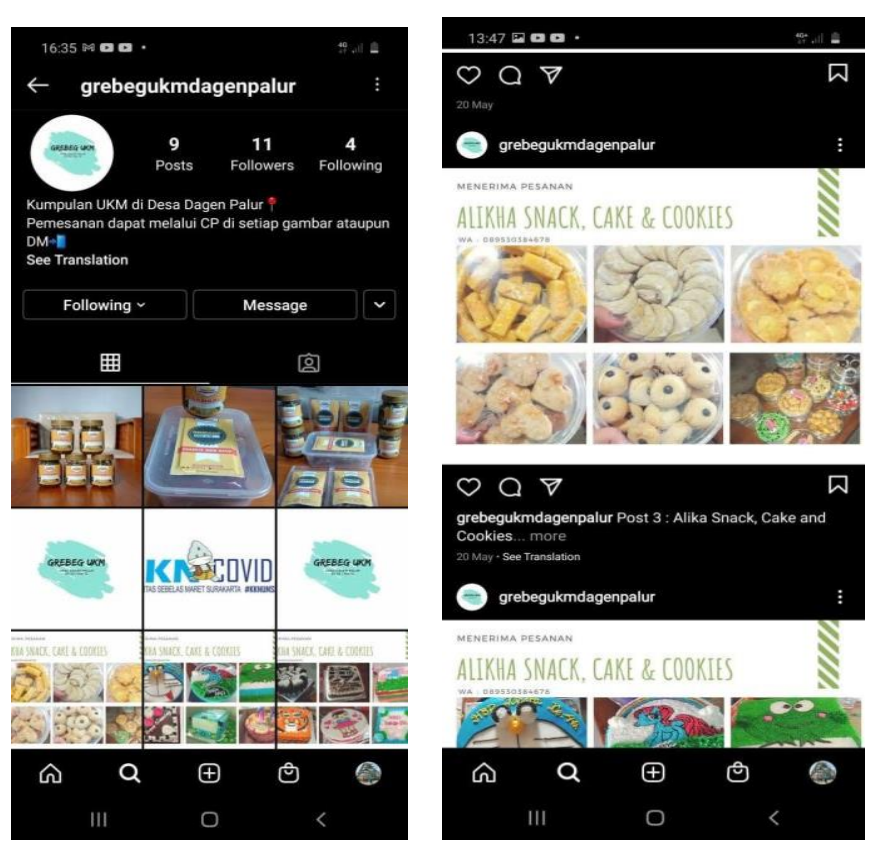
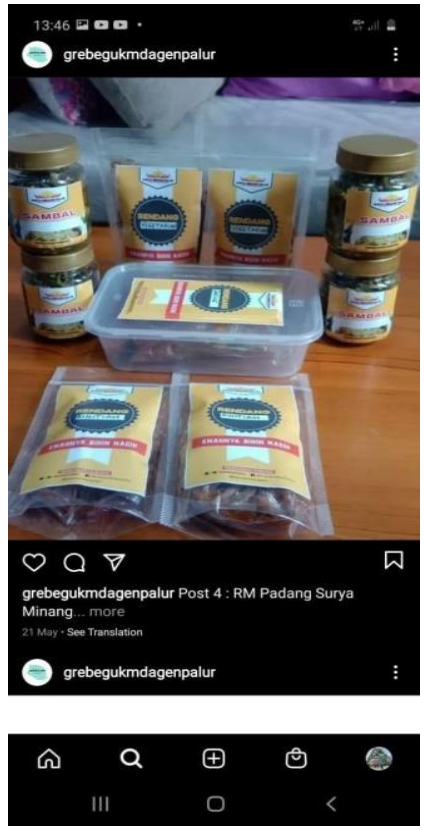
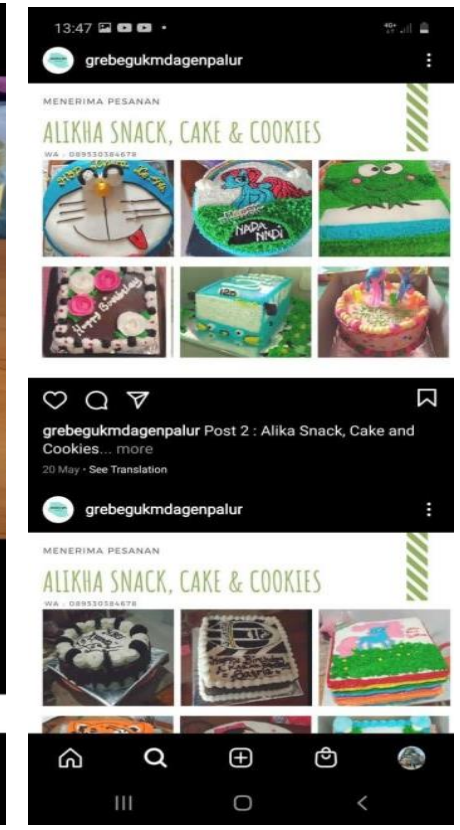

Gambar 4. Akun Instagram "grebegukmdagenpalur” dan beberapa contoh dagangan yang ditawarkan. 
Masyarakat lokasi KKN telah menerapkan E-commerce lewat wa group dan akun Instagram. Dari evaluasi yang telah dilakukan, masyarakat masih membutuhkan pendampingan terkait pembuatan konten promosi barang dagangan, cara membungkus (packing) barang dagangan, cara mengirim barang dagangan ke pembeli dan metode pembayaran dengan transfer uang. Jika dilihat dari metode E-commerce yang dilakukan, jual-beli dengan wa group lebih diminati oleh warga masyarakat karena lebih mudah bagi mereka untuk melaksanakan transaksi jual beli. Masyarakat sudah saling mengenal satu sama lain, sehingga kepercayaan terhadap kualitas barang dagangannya lebih besar dan proses pembayaran bisa dilakukan secara langsung (cash). Kekurangan jual beli dengan wa group adalah terbatasnya anggota wa group yang hanya sebatas anggota warga masyarakat lokasi KKN saja sehingga pangsa pasar lebih sempit. Metode E-commerce dengan akun Instagram dapat menjangkau masyarakat yang lebih luas, tidak hanya terbatas pada warga masyarakat di lokasi KKN saja. Kelemahan jual beli dengan akun Instagram bagi masyarakat lokasi KKN adalah keberanian masyarakat untuk bertransaksi kurang karena pembeli belum dikenal sebelumnya dan pembayaran dilakukan dengan transfer uang lewat rekening bank. Selain itu, warga masyarakat penjual merasa enggan kalau harus membungkus dan mengirimkan barang dagangan ke tempat lain.

Dari ketiga hasil media sosial yang dibuat untuk keperluan E-commerce di lokasi KKN pada masa pandemi Covid-19, maka masih banyak yang harus diperbaiki baik sarana dan prasarananya. Jika didukung dengan prasarana yang memadai maka E-commerce merupakan alternatif dalam melakukan bisnis bagi warga masyarakat di lokasi KKN. Media sosial dapat dijadikan sebagai media pemasaran yang efektif karena akses yang mudah dan cepat. Warga masyarakat dapat melaksanakan jual beli dengan tanpa ada batasan waktu dan wilayah (Achmad dkk, 2020). Kemajuan teknologi informasi dan komunikasi saat ini menjadi jalan untuk meningkatkan taraf hidup warga masyarakat. E-commerce dapat dimanfaatkan untuk mengembangkan segala potensi di daerah dalam berbagai sektor, yaitu pertanian, industri, UMKM, ekonomi kerakyatan dan lain sebagainya (Masykur dan Setyawan, 2019).

\section{Kesimpulan}

E-commerce menjadi salah satu jalan untuk mengembangkan usaha kecil dan menengah dan salah satu cara untuk mengurangi pengangguran. Dengan berkembangnya usaha kecil dan menengah akan menopang perekonomian masyarakat sehingga dapat meningkatkan taraf hidup masyarakat. Mengenalkan E-commerce kepada masyarakat di lokasi KKN telah dilakukan. Selama kegiatan KKN berlangsung, banyak pelanggan baru yang datang dan tertarik mencoba barang dagang dari yang ditawarkan baik di wa group maupun Instagram. Hal tersebut membuat geliat perekonomian di lokasi KKN terlihat. Namun diharapkan kegiatan promosi dagangan di media sosial perlu terus dibina dengan menampilkan foto-foto, gambar-gambar dan narasi yang bagus sehingga akan menarik konsumen yang lebih banyak. Peningkatan kesejahteraan masyarakat pada akhirnya akan terwujud.

\section{Ucapan Terima Kasih}

Penulis mengucapkan terima kasih kepada: (1). Ketua RT 05 RW II Kodokan, Desa Papahan, Tasikmadu, Karanganyar, (2). RT 02 RW V Dukuh Karangan, Ngunut, Jumantono, Karanganyar, dan (3). RT 02 RW V Dukuh Karangan, Ngunut, Jumantono, Karanganyar, yang telah memberi dukungan atas terlaksananya program KKN UNS Periode Mei-Juni 2020 ini.

\section{Daftar Pustaka}

Achmad, Z.A., Azhari, T.Z., Esfandiar, W.N., Nuryaningrum, N., Syifana, N.F.D., dan Cahyaningrum, I. (2020). Pemanfaatan Media Sosial dalam Pemasaran Produk UMKM di Kelurahan Sidokumpul, Kabupaten Gresik, Jurnal Ilmu Komunikasi, No.1, Vol. 10, 2020, 17-31.

Anwar, F., Suparmi, Cari, Riyatun, Suharyanto, Darmanto, dan Yuniawan, M. (2020). Optimalisasi Penjualan Produk Unggulan Wonorejo melalui Sosial Media pada Masa Pandemi COVID-19, Jurnal SEMAR, No.2, Vol.9, 1-8.

Ardiana, B., dan Subaedi. (2010). Kompetensi SDM UKM dan Pengaruhnya Terhadap Kinerja UKM di Surabaya, Jurnal Majemen dan Kewirausahaan, No.1, Vol.12, 42-55. 
Gambrien, B., Risnandar dan Iskandar, A.R. (2012). E-Commerce untuk Usaha Mikro, Kecil, dan Menengah (UMKM) (Studi Kasus: Kabupaten Tana Toraja, Sulawesi Selatan), Jurnal Teknologi Informasi Politeknik Telkom, No.4, Vol.1, 144-151.

Hadi, S., Wibowo, Triyono, J., Rujunia, L.O., and Nasrianto, L.O. (2020). Peningkatan Potensi Wisata Desa Waginopo dengan Mengoptimalkan Sumber Daya Melalui Program Ekonomi Kreatif, Jurnal SEMAR, Vol. 9 No. 1, 36-47.

Harapan, H., Itoh, N., Yufika, A., Winardi, W., Keam, S., Te, H., Megawati, D., Hayati, Z., Wagner, A.L., dan Mudatsir, M. (2020). Coronavirus disease-2019 (COVID-19); A literature review. Journal of Infection and Public Health. Vol.13, 1-7.

Masykur, F. dan Setyawan, M.B. (2019). Penerapan Smart E-Commerce Guna Pengembangan Produk LOkal Desa Tahunan Kecamatan Tegalombo Pacitan, Jurnal Adimas, No.1, Vol.3, 24-30.

Permana, A.E., Reyhan, A.M., Rafli, H., dan Rakhmawati, N.A. (2021). Analisa Transaksi Belanja Online pada Masa Pandemi Covid-19, Jurnal TEKNOINFO, No.1, Vol.15, 32-37.

Sari, D.E., Handoko, R. dan Rochim, A.I. (2018). Pengaruh Online Shop Jejaring Sosial Terhadap Perilaku Konsumtif Pada Ibu Rumah Tangga Kabupaten Mojokerto (Studi Kasus Ibu Rumah Tangga Di Desa Mojotamping, Kecamatan Bangsal, Kabupaten Mojokerto), Jurnal Representamen, No.1, Vol.4, 1-9.

Siregar, A.G.S., dan Widodo, A. (2018). Pengaruh Periklanan Sosial Media Terhadap Keputusan Pembelian Konsumen (Study Pada Konsumen Nasi Goreng Mafia di Kota Bandung), e-Proceeding of Management, No.1, Vol.5, 1131-1137.

Tanoto, S.R., dan Evelyn. (2019). Financial Knowledge, Financial Wellbeing and Online Shopping Addiction among Young Indonesians. Jurnal Majemen dan Kewirausahaan, No.1, Vol.2, 32-40.

Tohardi, A. (2002). Pemahaman Praktis Manajemen Sumber Daya Manusia, Mandar Maju, Bandung.

Yuliana, (2020). Corona Virus Diseases (Covid-19); Sebuah Tinjauan Literatur. Wellness and Healthy Magazine. No.1, Vol.2, 187-92. 